\title{
France, Russia, China: A Structural Analysis of Social Revolutions
}

\author{
THEDA SKOCPOL \\ Harvard University
}

'A revolution', writes Samuel P. Huntington in Political Order in Changing Societies, 'is a rapid, fundamental, and violent domestic change in the dominant values and myths of a society, in its political institutions, social structure, leadership, and government activities and policies'. ${ }^{1}$ In The Two Tactics of Social Democracy in the Democratic Revolution, Lenin provides a different, but complementary perspective: 'Revolutions', he says, 'are the festivals of the oppressed and the exploited. At no other time are the masses of the people in a position to come forward so actively as creators of a new social order'. ${ }^{2}$

Together these two quotes delineate the distinctive features of social revolutions. As Huntington points out, social revolutions are rapid, basic transformations of socio-economic and political institutions, and-as Lenin so vividly reminds us-social revolutions are accompanied and in part effectuated through class upheavals from below. It is this combination of thoroughgoing structural transformation and massive class upheavals that sets social revolutions apart from coups, rebellions, and even political revolutions and national independence movements.

If one adopts such a specific definition, then clearly only a handful of successful social revolutions have ever occurred. France, 1789, Russia, 1917, and China, 1911-49, are the most dramatic and clear-cut instances. Yet these momentous upheavals have helped shape the fate of the majority of mankind, and their causes, consequences, and poten-

This article represents a shortened and revised version of a paper presented at the Session on Revolutions of the 1973 Meetings of the American Sociological Association. For criticism, advice (not all of it heeded), intellectual stimulation and encouragement offered to the author in the long course of preparing this paper, thanks go to: Daniel Bell, Mounira Charrad, Linda Frankel, George Homans, S. M. Lipset, Gary Marx, John Mollenkopf, Barrington Moore, Jr., Bill Skocpol, Sylvia Thrupp and Kay Trimberger.

1 Samuel P. Huntington, Political Order in Changing Societies (New Haven: Yale University Press, 1968), p. 264.

2 Stephan T. Possony, ed., The Lenin Reader (Chicago: Henry Regnery Company, 1966), p. 349. 
tials have preoccupied many thoughtful people since the late eighteenth century.

Nevertheless, recently, social scientists have evidenced little interest in the study of social revolutions as such. They have submerged revolutions within more general categories-such as 'political violence', 'collective behavior', 'internal war', or 'deviance'-shorn of historical specificity and concern with large-scale social change. ${ }^{3}$ The focus has been mostly on styles of behavior common to wide ranges of collective incidents (ranging from riots to coups to revolutions, from panics to hostile outbursts to 'value-oriented movements', and from ideological sects to revolutionary parties), any of which might occur in any type of society at any time or place. Revolutions tend increasingly to be viewed not as 'locomotives of history', but as extreme forms of one or another sort of behavior that social scientists, along with established authorities everywhere, find problematic and perturbing.

Why this avoidance by social science of the specific problem of social revolution? Ideological bias might be invoked as an explanation, but even if it were involved, it would not suffice. An earlier generation of American social scientists, certainly no more politically radical than the present generation, employed the 'natural history' approach to analyze handfuls of cases of great revolutions. ${ }^{4}$ In large part, present preoccupation with broader categories can be understood as a reaction against this natural history approach, deemed by its critics too 'historical' and 'a-theoretical'.

In the 'Introduction' to a 1964 book entitled Internal War, Harry Eckstein defines 'a theoretical subject' as a 'set of phenomena about which one can develop informative, testable generalizations that hold for all instances of the subject, and some of which apply to those instances alone'. ${ }^{5}$ He goes on to assert that while 'a statement about two or three cases is certainly a generalization in the dictionary sense, a generalization in the methodological sense must usually be based on more; it ought to cover a number of cases large enough for certain rigorous testing procedures like statistical analysis to be used'. ${ }^{6}$ Even many social scientists who are not statistically oriented would agree with the spirit of this statement:

${ }^{3}$ For important examples see: Ted Robert Gurr, Why Men Rebel (Princeton, New Jersey: Princeton University Press, 1970); Neil J. Smelser, Theory of Collective Behavior (New York: The Free Press of Glencoe, 1963), and Harry Eckstein, 'On the Etiology of Internal Wars', History and Theory 4(2) (1965).

4 Crane Brinton, The Anatomy of Revolution (New York: Vintage Books, 1965; original edition, 1938); Lyford P. Edwards, The Natural History of Revolution (Chicago: University of Chicago Press, 1971; originally published in 1927); George Sawyer Petee, The Process of Revolution (New York: Harper and Brothers, 1938); and Rex D. Hopper, 'The Revolutionary Process', Social Forces 28 (March, 1950): $270-9$.

5 Harry Eckstein, ed., Internal War (New York: The Free Press, 1964), p. 8.

I Ibid., p. 10. 
theory in social science should concern itself only with general phenomena; the 'unique' should be relegated to 'narrative historians'.

Apparently it directly follows that no theory specific to social revolution is possible, that the explanandum of any theory which sheds light on social revolutions must be something more general than social revolution itself. Hence the efforts to conceptualize revolution as an extreme instance of patterns of belief or behavior which are also present in other situations or events.

This approach, however, allows considerations of technique to define away substantive problems. Revolutions are not just extreme forms of individual or collective behavior. They are distinctive conjunctures of socio-historical structures and processes. One must comprehend them as complex wholes-however few the cases-or not at all.

Fortunately social science is not devoid of a way of confronting this kind of problem. Social revolutions can be treated as a 'theoretical subject'. To test hypotheses about them, one may employ the comparative method, with national historical trajectories as the units of comparison. As many students of society have noted, the comparative method is nothing but that mode of multivariate analysis to which sociologists necessarily resort when experimental manipulations are not possible and when there are 'too many variables and not enough cases'- that is, not enough cases for statistical testing of hypotheses. ${ }^{7}$ According to this method, one looks for concomitant variations, contrasting cases where the phenomena in which one is interested are present with cases where they are absent, controlling in the process for as many sources of variation as one can, by contrasting positive and negative instances which otherwise are as similar as possible.

Thus, in my inquiry into the conditions for the occurrence and shortterm outcomes of the great historical social revolutions in France, Russia and China, I have employed the comparative historical method, specifically contrasting the positive cases with (a) instances of non-social revolutionary modernization, such as occurred in Japan, Germany and Russia (up to 1904), and with (b) instances of abortive social revolutions, in particular Russia in 1905 and Prussia/Germany in 1848. These comparisons have helped me to understand those aspects of events and of structures and processes which distinctively rendered the French, Chinese and Russian Revolutions successful social revolutions. In turn, the ab-

\footnotetext{
7 See: Ernest Nagel, ed., John Stuart Mill's Philosophy of Scientific Method (New York: Hafner Publishing Co., 1950); Marc Bloch, "Toward a Comparative History of European Societies', in Frederic C. Lane and Jelle C. Riemersma, eds., Enterprise and Secular Change (Homewood, Illinois: The Dorsey Press, 1953), pp. 494-521; William H. Sewell, Jr., 'Marc Bloch and the Logic of Comparative History', History and Theory 6(2) (1967): 208-18; Neil J. Smelser, 'The Methodology of Comparative Analysis', (unpublished draft); and S. M. Lipset, Revolution and Counterrevolution (New York: Anchor Books, 1970), part I.
} 
sence of conditions identified as positively crucial in France, Russia and China constitutes equally well an explanation of why social revolutions have not occurred, or have failed, in other societies. In this way, hypotheses developed, refined, and tested in the comparative historical analysis of a handful of cases achieve a potentially general significance.

EXPLAINING THE HISTORICAL CASES:

REVOLUTION IN MODERNIZING AGRARIAN

B U R E A U C R A I E S

Social revolutions in France, Russia and China occurred, during the earlier world-historical phases of modernization, in agrarian bureaucratic societies situated within, or newly incorporated into, international fields dominated by more economically modern nations abroad. In each case, social revolution was a conjuncture of three developments: (1) the collapse or incapacitation of central administrative and military machineries; (2) widespread peasant rebellions; and (3) marginal elite political movements. What each social revolution minimally 'accomplished' was the extreme rationalization and centralization of state institutions, the removal of a traditional landed upper class from intermediate (regional and local) quasi-political supervision of the peasantry, and the elimination or diminution of the economic power of a landed upper class.

In the pages that follow, I shall attempt to explain the three great historical social revolutions, first, by discussing the institutional characteristics of agrarian states, and their special vulnerabilities and potentialities during the earlier world-historical phases of modernization, and second, by pointing to the peculiar characteristics of old regimes in France, Russia and China, which made them uniquely vulnerable among the earlier modernizing agrarian states to social-revolutionary transformations. Finally, I shall suggest reasons for similarities and differences in the outcomes of the great historical social revolutions.

An agrarian bureaucracy is an agricultural society in which social control rests on a division of labor and a coordination of effort between a semi-bureaucratic state and a landed upper class. ${ }^{8}$ The landed upper class typically retains, as an adjunct to its landed property, considerable (though varying in different cases) undifferentiated local and regional authority over the peasant majority of the population. The partially bu-

8 In formulating the 'agrarian bureaucracy' societal type concept, I have drawn especially upon the work and ideas of S. N. Eisenstadt in The Political Systems of Empires (New York: The Free Press, 1963); Barrington Moore, Jr., in Social Origins of Dictatorship and Democracy (Boston: Beacon Press, 1967); and Morton H. Fried, 'On the Evolution of Social Stratification and the State', pp. 713-31 in Stanley Diamond, ed., Culture in History (New York: Columbia University Press, 1960). The label 'agrarian bureaucracy' is pilfered from Moore. Clear-cut instances of agrarian bureaucratic societies were: China, Russia, France, Prussia, Austria, Spain, Japan, Turkey. 
reaucratic central state extracts taxes and labor from peasants either indirectly through landlord intermediaries or else directly, but with (at least minimal) reliance upon cooperation from individuals of the landed upper class. In turn, the landed upper class relies upon the backing of a coercive state to extract rents and/or dues from the peasantry. At the political center, autocrat, bureaucracy, and army monopolize decisions, yet (in varying degrees and modes) accommodate the regional and local power of the landed upper class and (again, to varying degrees) recruit individual members of this class into leading positions in the state system.

Agrarian bureaucracies are inherently vulnerable to peasant rebellions. Subject to claims on their surpluses, and perhaps their labor, by landlords and state agents, peasants chronically resent both. To the extent that the agrarian economy is commercialized, merchants are also targets of peasant hostility. In all agrarian bureaucracies at all times, and in France, Russia and China in non-revolutionary times, peasants have had grievances enough to warrant, and recurrently spur, rebellions. Economic crises (which are endemic in semi-commercial agrarian economies anyway) and/or increased demands from above for rents or taxes might substantially enhance the likelihood of rebellions at particular times. But such events ought to be treated as short-term precipitants of peasant unrest, not fundamental underlying causes.

Modernization is best conceived not only as an intrasocietal process of economic development accompanied by lagging or leading changes in non-economic institutional spheres, but also as a world-historic intersocietal phenomenon. Thus,

a necessary condition of a society's modernization is its incorporation into the historically unique network of societies that arose first in Western Europe in early modern times and today encompasses enough of the globe's population for the world to be viewed for some purposes as if it consisted of a single network of societies. ${ }^{9}$

Of course, societies have always interacted. What was special about the modernizing intersocietal network that arose in early modern Europe was, first, that it was based upon trade in commodities and manufactures, as well as upon strategic politico-military competition between independent states, ${ }^{10}$ and, second, that it incubated the "first (self-propelling) industrialization' of England after she had gained commercial hegemony within the Western European-centered world market. ${ }^{11}$

In the wake of that first commercial-industrial breakthrough, modernizing pressures have reverberated throughout the world. In the first phase

9 Terence $\mathrm{K}$. Hopkins and Immanuel Wallerstein, The Comparative Study of National Societies', Social Science Information 6 (1967), 39.

10 See Immanuel Wallerstein, The Modern World System: Capitalist Agriculture and the Origins of the European World-Economy in the Sixteenth Century (New York and London: Academic Press, 1974).

11 E. J. Hobsbawm, Industry and Empire (Baltimore, Md.: Penguin Books, 1969). 
of world modernization, England's thoroughgoing commercialization, capture of world market hegemony, and expansion of manufactures (both before and after the technological Industrial Revolution which began in the 1780s), transformed means and stakes in the traditional rivalries of European states and put immediate pressure for reforms, if only to facilitate the financing of competitive armies and navies, upon the other European states and especially upon the ones with less efficient fiscal machineries. ${ }^{12}$ In the second phase, as Europe modernized and further expanded its influence around the globe, similar militarily compelling pressures were brought to bear on those non-European societies which escaped immediate colonization, usually the ones with pre-existing differentiated and centralized state institutions.

During these phases of global modernization, independent responses to the dilemmas posed by incorporation into a modernizing world were possible and (in some sense) necessary for governmental elites in agrarian bureaucracies. Demands for more and more efficiently collected taxes; for better and more generously and continuously financed militaries; and for 'guided' national economic development, imitating the available foreign models, were voiced within these societies especially by bureaucrats and the educated middle strata. The demands were made compelling by international military competition and threats. At the same time, governmental leaders did have administrative machineries, however rudimentary, at their disposal for the implementation of whatever modernizing reforms seemed necessary and feasible (at given moments in world history). And their countries had not been incorporated into dependent economic and political positions in a world stratification system dominated by a few fully industrialized giants.

But agrarian bureaucracies faced enormous difficulties in meeting the crises of modernization. Governmental leaders' realm of autonomous action tended to be severely limited, because few fiscal or economic reforms could be undertaken which did not encroach upon the advantages of the traditional landed upper classes which constituted the major social base of support for the authority and functions of the state in agrarian bureaucracies. Only so much revenue could be squeezed out of the peasantry, and yet landed upper classes could often raise formidable obstacles to rationalization of tax systems. Economic development might mean more tax revenues and enhanced military prowess, yet it channelled wealth and manpower away from the agrarian sector. Finally, the mobilization of mass popular support for war tended to undermine the traditional, local authority of landlords or landed bureaucrats upon which agrarian bureaucratic societies partly relied for the social control of the peasantry.

12 See Walter L. Dorn, Competition for Empire, 1740-1763 (New York: Harper and Row, 1963; originally, 1940). 
Agrarian bureaucracies could not indefinitely 'ignore' the very specific crises, in particular fiscal and martial, that grew out of involvement with a modernizing world, yet they could not adapt without undergoing fundamental structural changes. Social revolution helped accomplish 'necessary' changes in some but was averted by reform or 'revolution from above' in others. Relative stagnation, accompanied by sub-incorporation into international power spheres, was still another possibility (e.g., Portugal, Spain?). Social revolution was never deliberately 'chosen'. Societies only 'backed into' social revolutions.

All modernizing agrarian bureaucracies have peasants with grievances and face the unavoidable challenges posed by modernization abroad. So, in some sense, potential for social revolution has been built into all modernizing agrarian bureaucracies. Yet, only a handful have succumbed. Why? A major part of the answer, I believe, lies in the insight that 'not oppression, but weakness, breeds revolution'. ${ }^{13}$ It is the breakdown of a societal mode of social control which allows and prompts social revolution to unfold. In the historical cases of France, Russia and China, the unfolding of social revolution depended upon the emergence of revolutionary crises occasioned by the incapacitation of administrative and military organizations. That incapacitation, in turn, is best explained not as a function of mass discontent and mobilization, but as a function of a combination of pressures on state institutions from more modernized countries abroad, and (in two cases out of three) built-in structural incapacities to mobilize increased resources in response to those pressures. France, Russia and China were also special among all agrarian bureaucracies in that their agrarian institutions afforded peasants not only the usual grievances against landlords and state agents but also 'structural space' for autonomous collective insurrection. Finally, once administrative/military breakdown occurred in agrarian bureaucracies with such especially insurrection-prone peasantries, then, and only then, could organized revolutionary leaderships have great impact upon their societies' development-though not necessarily in the ways they originally envisaged.

BREAKDOWN OF SOCIETAL CONTROLS: FOREIGN PRESSURES AND ADMINISTRATIVE/MILITARY C O L L A P S E

If a fundamental cause and the crucial trigger for the historical social revolutions was the incapacitation of administrative and military machineries in modernizing agrarian bureaucracies, then how and why did this occur in France, Russia and China? What differentiated these agrar-

13 Christopher Lasch, The New Radicalism in America (New York: Vintage Books, 1967), p. 141. 
ian bureaucracies which succumbed to social revolution from others which managed to respond to modernizing pressures with reforms from above? Many writers attribute differences in response to qualities of will or ability in governmental leaders. From a sociological point of view, a more satisfying approach might focus on the interaction between (a) the magnitude of foreign pressures brought to bear on a modernizing agrarian bureaucracy, and (b) the particular structural characteristics of such societies that underlay contrasting performances by leaders responding to foreign pressures and internal unrest.

Overwhelming foreign pressures on an agrarian bureaucracy could cut short even a generally successful government program of reforms and industrialization 'from above'. Russia is the obvious case in point. From at least the 1890 s onward, the Czarist regime was committed to rapid industrialization, initially government-financed out of resources squeezed from the peasantry, as the only means of rendering Russia militarily competitive with Western nations. Alexander Gerschenkron argues that initial government programs to promote heavy industry had succeeded in the 1890 s to such an extent that, when the government was forced to reduce its direct financial and administrative role after 1904, Russia's industrial sector was nevertheless capable of autonomously generating further growth (with the aid of foreign capital investments.) ${ }^{14}$ Decisive steps to modernize agriculture and free peasant labor for permanent urban migration were taken after the unsuccessful Revolution of $1905 .{ }^{15} \mathrm{Had}$ she been able to sit out World War I, Russia might have recapitulated the German experience of industrialization facilitated by bureaucratic guidance.

But participation in World War I forced Russia to fully mobilize her population including her restive peasantry. Army officers and men were subjected to years of costly fighting, and civilians to mounting economic privations-all for nought. For, given Russia's 'industrial backwardness ... enhanced by the fact that Russia was very largely blockaded . . .', plus the 'inferiority of the Russian military machine to the German in everything but sheer numbers ..., military defeat, with all of its inevitable consequences for the internal condition of the country, was very nearly a foregone conclusion'. ${ }^{16}$ The result was administrative demoralization and paralysis, and the disintegration of the army. Urban insurrections which brought first middle-strata moderates and then the Bolsheviks to

14 Alexander Gerschenkron, 'Problems and Patterns of Russian Economic Development', pp. 42-72 in Cyril E. Black, ed., The Transformation of Russian Society (Cambridge, Mass.: Harvard University Press, 1960).

${ }_{15}$ Geroid Tanquary Robinson, Rural Russia Under the Old Regime (Berkeley and Los Angeles: University of California Press, 1969; originally published in 1932), Chap. 11.

16 William Henry Chamberlin, The Russian Revolution, Volume I (New York: Grosset and Dunlap, 1963; originally published in 1935), pp. 64-65. 
power could not be suppressed, owing to the newly-recruited character and war weariness of the urban garrisons. ${ }^{17}$ Peasant grievances were enhanced, young peasant men were politicized through military experiences, and, in consequence, spreading peasant insurrections from the spring of 1917 on could not be controlled.

It is instructive to compare 1917 to the Revolution of 1905 . Trotsky called 1905 a 'dress rehearsal' for 1917 , and, indeed, many of the same social forces with the same grievances and similar political programs took part in each revolutionary drama. What accounts for the failure of the Revolution of 1905 was the Czarist regime's ultimate ability to rely upon the army to repress popular disturbances. Skillful tactics were involved: the regime bought time to organize repression and assure military loyalty with well-timed liberal concessions embodied in the October Manifesto of 1905 (and later largely retracted). Yet, it was of crucial importance that the futile 1904-05 war with Japan was, in comparison with the World War I morass, circumscribed, geographically peripheral, less demanding of resources and manpower, and quickly concluded once defeat was apparent. ${ }^{18}$ The peace treaty was signed by late 1905 , leaving the Czarist government free to bring military reinforcements back from the Far East into European Russia.

The Russian Revolution occurred in 1917 because Russia was too inextricably entangled with foreign powers, friend and foe, economically and militarily more powerful than she. Foreign entanglement must be considered not only to explain the administrative and military incapacitation of 1917, but also entry into World War I. That involvement cannot be considered 'accidental'. Nor was it 'voluntary' in the same sense as Russia's entry into the 1904 war with Japan. ${ }^{19}$ Whatever leadership 'blunders' were involved, the fact remains that in 1914 both the Russian state and the Russian economy depended heavily on Western loans and capital. Moreover, Russia was an established part of the European state system and could not remain neutral in a conflict that engulfed the whole of that system. ${ }^{20}$

Foreign pressures and involvements so inescapable and overwhelming as those that faced Russia in 1917 constitute an extreme case for the earlier modernizing agrarian bureaucracies we are considering here. For

17 Katharine Chorley, Armies and the Art of Revolution (London: Faber and Faber, 1943), Chap. 6.

18 Ibid., pp. 118-9.

19 In 1904, "[t]he Minister of Interior, von Plehve, saw a desirable outlet from the [turbulent domestic] situation in a "little victorious war"' (Chamberlin, op. cit., p. 47).

20 See: Leon Trotsky, The Russian Revolution (selected and edited by F. W. Dupee) (New York: Anchor Books, 1959; originally published in 1932), Volume I, Chap. 2; and Roderick E. McGrew, 'Some Imperatives of Russian Foreign Policy', pp. 202-29 in Theofanis George Stavrou, ed., Russia Under the Last Tsar (Minneapolis: University of Minnesota Press, 1969). 


\section{84 THEDA SKOCPOL}

France and China the pressures were surely no more compelling than those faced by agrarian bureaucracies such as Japan, Germany and Russia (1858-1914) which successfully adapted through reforms from above that facilitated the extraordinary mobilization of resources for economic and military development. Why were the Bourbon and Manchu regimes unable to adapt? Were there structural blocks to effective response? First, let me discuss some general characteristics of all agrarian states, and then point to a peculiar structural characteristic shared by Bourbon France and Manchu China which I believe explains these regimes' inability to meet snow-balling crises of modernization until at last their feeble attempts triggered administrative and military disintegration, hence revolutionary crises.

Weber's ideal type of bureaucracy may be taken as an imaginary model of what might logically be the most effective means of purposively organizing social power. According to the ideal type, fully developed bureaucracy involves the existence of an hierarchically arrayed officialdom, where officials are oriented to superior authority in a disciplined manner because they are dependent for jobs, livelihood, status and careeradvancement on resources and decisions channeled through that superior authority. But in preindustrial states, monarchs found it difficult to channel sufficient resources through the 'center' to pay simultaneously for wars, culture and court life on the one hand, and a fully bureaucratic officialdom on the other. Consequently, they often had to make do with 'officials' recruited from wealthy backgrounds, frequently, in practice, landlords. In addition, central state jurisdiction rarely touched local peasants or communities directly; governmental functions were often delegated to landlords in their 'private' capacities, or else to non-bureaucratic authoritative organizations run by local landlords.

Inherent in all agrarian bureaucratic regimes were tensions between, on the one hand, state elites interested in preserving, using, and extending the powers of armies and administrative organizations and, on the other hand, landed upper classes interested in defending locally and regionally based social networks, influence over peasants, and powers and privileges associated with the control of land and agrarian surpluses. Such tensions were likely to be exacerbated once the agrarian bureaucracy was forced to adapt to modernization abroad because foreign military pressures gave cause, while foreign economic development offered incentives and models, for state elites to attempt reforms which went counter to the class interests of traditional, landed upper strata. Yet there were important variations in the ability of semi-bureaucratic agrarian states to respond to modernizing pressures with reforms which sharply and quickly increased resources at the disposal of central authorities. What can account for the differences in response? 
Not the values or individual qualities of traditional bureaucrats: Japan's Meiji reformers acted in the name of traditional values and authority to enact sweeping structural reforms which cleared the way for rapid industrialization and military modernization. Russia's czarist officialdom was renowned for its inefficiency and corruption, and yet it implemented basic agrarian reforms in 1861 and 1905 and administered the first stages of heavy industrialization.

Leaving aside value-orientations and individual characteristics, we must look at the class interests and connections of state officials. The adaptiveness of the earlier modernizing agrarian bureaucracies was significantly determined by the degree to which the upper and middle ranks of the state administrative bureaucracies were staffed by large landholders. Only state machineries significantly differentiated from traditional landed upper classes could undertake modernizing reforms which almost invariably had to encroach upon the property or privileges of the landed upper class.

Thus, in an analysis of what she calls 'elite revolutions' in Japan (1863) and Turkey (1919), Ellen Kay Trimberger argues that segments of the traditional leaderships of those agrarian bureaucracies were able to respond so effectively to intrusions by more modern powers only because 'the Japanese and Turkish ruling elites were political bureaucrats without vested economic interests. . . ${ }^{\prime 21}$ Similarly Walter M. Pintner concludes from his careful research into 'The Social Characteristics of the Early Nineteenth-Century Russian Bureaucracy' that:

By the end of the eighteenth century the civil bureaucracy in the central agencies, and by the 1850 s in the provinces also, was an essentially self-perpetuating group. Recruits came from a nobility that was in large measure divorced from the land, and from among the sons of nonnoble government workers (military, civil, and ecclesiastical)... What is important is that the state's civil administration, even at the upper levels, was staffed with men who were committed to that career and no other and who seldom had any other significant source of income. The competence, efficiency, and honesty of the civil service were undoubtedly very low, . . . however, it should have been a politically loyal instrument, and indeed it proved to be when the tsar determined to emancipate the serfs and assign to them land that was legally the property of the nobility. 22

But where-as in Bourbon France and late Manchu China-regionally-based cliques of landed magnates were ensconced within nominally centralized administrative systems, the ability of the state elites to control

21 Ellen Kay Trimberger, 'A Theory of Elite Revolutions', Studies in Comparative International Development 7(3) (Fall, 1972), p. 192.

22 Walter M. Pintner, 'The Social Characteristics of the Early Nineteenth-Century Russian Bureaucracy', Slavic Review 29(3) (September, 1970), 442-3. See also, Don Karl Rowney, 'Higher Civil Servants in the Russian Ministry of Internal Affairs: Some Demographic and Career Characteristics, 1905-1916', Slavic Review 31(1) (March, 1972): 101-10. 
the flow of tax resources and implement reform policies was decisively undermined. By their resistance to the mobilization of increased resources for military or economic purposes in modernization crises, such landed cliques of officials could engender situations of acute administrative/military disorganization-potentially revolutionary crises of governmental authority.

The French monarchy struggled on three fronts throughout the eighteenth century. ${ }^{23}$ Within the European state system, France's 'amphibious geography' forced her to compete simultaneously with the great continental land powers, Austria and (after mid-century) Prussia, and with the maritime powers, above all, Britain. Britain's accelerating commercial and industrial development put France at ever increasing disadvantage in trade and naval strength and the extraordinary efficiency of Prussia's bureaucratic regime, its special ability to extract resources from relatively poor people and territories and to convert them with minimal wastage to military purposes, tended to compensate for France's advantages of national wealth and territorial size. And the French monarchy had to fight on a 'third front' at home-against the resistance of its own privileged strata to rationalization of the tax system.

Perceptive as he was in pointing to rationalization and centralization of state power as the most fateful outcomes of the French Revolution, Alexis de Tocqueville ${ }^{24}$ surely exaggerated the extent to which monarchical authority already exhibited those qualities before the Revolution. To be sure:

At first view France, the historic center of continental statecraft, presents the picture of a clear, homogeneous and consistent governmental structure. The king was the sole legislator, the supreme chief of the administrative hierarchy and the source of all justice. ... A All authority was delegated by the crown, and its agents, whether ministers, provincial intendants or subdelegates, were its mandatories. . . In the matter of justice the council of state, acting as the king's private court, could override judgements of all ordinary courts. The sovereign's parlements, the intermediary and lower courts pronounced justice in the king's name, and even the seigneurial, municipal, and ecclesiastical courts were subject to his control ... The Estates General were no more and the few remaining provincial estates were reduced to pure administrative bodies. ${ }^{25}$

Such was the system in theory, an absolute monarch's dream. But in practice? Quite aside from general qualities which set the French administrative system in the eighteenth century in sharp contrast to the Prussian -as 'more disjointed, less uniform, less effectively geared by control devices, above all less firmly co-ordinated by a single driving purpose pene-

${ }^{23}$ Dorn, op. cit.; and C. B. A. Behrens, The Ancien Regime (London: Harcourt, Brace, and World, 1967).

${ }_{24}$ Alexis de Tocqueville, The Old Regime and the French Revolution (New York: Anchor Books, 1955; originally published in French in 1856).

25 Dorn, op. cit., p. 23. 
trating the entire administrative hierarchy'28 - the system afforded landlords (and wealth-holders generally) strategic points of institutional leverage for obstructing royal policies.

A substantial number of the First and Second Estates was obviously still trying to live in terms of the old feudal structure that had lost its functional justification at least two centuries before ... [T] [Te residue is not hard to identify or describe. Characteristically it was composed of the larger landowners, but not the princes of the realm nor even the constant residents at Versailles. The latter had obviously, if not necessarily willingly, cast their lot with the King. Similarly, many of the lesser nobles had, whether from ambition or necessity, taken service in the army or, occasionally, in the administration. The remaining survivors of the old feudal classes, however, tended to live on their properties in the provinces, serve and subvert the local bureaucracy, seek preferment in the Church, and find expression and defense of their interests through the provincial estates and parlements. 27

The parlements, or sovereign courts, nominally a part of the administrative system, were the most avid and strategically located of the institutional defenders of property and privilege. 'The French monarchy never remedied its fatal error of having sold judicial offices just at the moment when it became master of the political machine. The monarch was almost completely powerless in the face of his judges, whom he could not dismiss, transfer, or promote'. ${ }^{28}$

Magistrates of the parlements varied markedly in the length of their noble pedigrees, but virtually all were men of considerable wealth, '. . for their fortunes included not only their offices, in themselves representing large investments, but also a formidable accumulation of securities, urban property, and rural seigneuries. ${ }^{29}$ As courts of appeal for disputes about seigneurial rights, the parlements played a crucial role in defending this 'bizarre form of property' held by noble and bourgeois alike. ${ }^{30}$ 'Indeed, without the juridical backing of the parlements the whole system of seigneurial rights might have collapsed, for the royal officials had no in-

26 Ibid., p. 30.

27 Edward Whiting Fox, History in Geographic Perspective: The Other France (New York: W. W. Norton, 1971), p. 69.

28 Dorn, op. cit., p. 26.

${ }^{29}$ Franklin L. Ford, Robe and Sword (New York: Harper and Row, 1965; originally published in 1953), p. 248.

30 Alfred Cobban, The Social Interpretation of the French Revolution (Cambridge: Cambridge University Press, 1968), Chaps. 4 and 5. There is growing agreement among historians that, at the end of the Ancien Régime, there was, 'between most of the nobility and the proprietary sector of the middle classes, a continuity of investment forms and socio-economic values that made them, economically, a single group. In the relations of production they played a common role. The differentiation between them was not in any sense economic; it was juridical'. From George Taylor, 'Noncapitalist Wealth and the Origins of the French Revolution', American Historical Review 72(2) (January, 1967), pp. 487-8. Similar views are expressed by J. McManners, 'France', pp. 22-42 in Albert Goodwin, ed., The European Nobility in the Eighteenth Century (New York: Harper and Row, 1967; originally published in 1953); and Behrens, op. cit., pp. 46-84. 
terest in the maintenance of a system which removed income from those who were taxable into the hands of those who could not be taxed'. ${ }^{31}$

Not surprisingly, given their property interests and extensive connections with non-magisterial propertied families, the parlementaires were avid defenders of the rights and privileges of the upper classes in general. 'By their remonstrances and by their active participation in the surviving provincial estates the magistrates proceeded to uphold . . . opposition to undifferentiated taxation, encroachments on seigneurial autonomy, and ministerial assaults on the fortress of regional particularism. ${ }^{32}$ By their dogged defense of tax and property systems increasingly inadequate to the needs of the French state in a modernizing world, the parlements throughout the eighteenth century repeatedly blocked attempts at reform. Finally, in $1787-88$, they '. . . opened the door to revolution' 33 by rallying support against now indispensable administrative fiscal reforms, and by issuing the call for the convening of the Estates General.

France fought at sea and on land in each of the general European wars of the eighteenth century: the War of the Austrian Succession; the Seven Years War; and the war over American Independence. In each conflict, her resources were strained to the utmost and her vital colonial trade disrupted, yet no gains, indeed losses in America and India, resulted. ${ }^{34}$ The War for American Independence proved to be the last straw. '[T] he price to be paid for American Independence was a French Revolution:' ${ }^{35}$ royal treasurers finally exhausted their capacity to raise loans from financiers, and were forced (again) to propose reforms of the tax system. The usual resistance from the parlements ensued, and an expedient adopted by Calonne in an attempt to circumvent it-the summoning of an Assembly of Notables in 1787-only provided privileged interests yet another platform for voicing resistance. A last-ditch effort to override the parlements (by Brienne in 1787-88) crumbled in the face of concerted upper-class defiance, popular demonstrations, and the unwillingness of army officers to direct forcible suppression of the popular resistance. ${ }^{36}$

The army's hesitance was especially crucial in translating fiscal crises and political unrest into general administrative and military breakdown. Recruited from various privileged social backgrounds-rich noble, rich non-noble, and poor country noble-the officers had a variety of longstanding grievances, against other officers and, significantly, against the

31 Alfred Cobban, A History of Modern France, Volume I: 1715-1799 (Baltimore, Md.: Penguin Books, 1963; originally published in 1957), p. 155.

32 Ford, op. cit., p. 248.

33 Cobban, $A$ History . . , p. 68.

34 Dorn, op. cit.

35 Cobban, $A$ History . . , p. 122.

36 Jean Egret, La Pré-Revolution Française, 1787-1788 (Paris: Presses Universitaires de France, 1962). 
Crown, which could never satisfy them all. ${ }^{37}$ But it is likely that the decisive explanation for their behavior lies in the fact that they were virtually all privileged, socially and/or economically, and hence identified during 1787-88 with the parlements. In her Armies and the Art of Revolution, Katharine Chorley concludes from comparative historical studies that, in preindustrial societies, army officers generally identify with and act to protect the interests of the privileged strata from which they are recruited. During its opening phases, until after the King had capitulated and agreed to convene the Estates General, the French Revolution pitted all strata, led by the privileged, against the Crown. The army officers' understandable reluctance to repress popular unrest during that period created a general crisis of governmental authority and effectiveness which in turn unleashed social divisions, between noble and non-noble, rich and poor, that made a subsequent resort to simple repression by the Old Regime impossible.

The officers' insubordination early in the Revolution was all the more easily translated into rank-and-file insubordination in 1789 and after, because of the fact that French soldiers were not normally insulated from the civilian population. Soldiers were billeted with civilians, and those from rural areas were released during the summers to help with the harvest at home. Thus, during 1789, the Gardes Françaises (many of whom were married to Parisian working-class women) were won over to the Paris revolution in July, and peasant soldiers spread urban news in the countryside during the summer and returned to their units in the autumn with vivid tales of peasant revolt. ${ }^{38}$

Like the Bourbon Monarchy, the Manchu Dynasty proved unable to mobilize resources sufficient to meet credibly the challenges posed by involvement in the modernizing world. '[T]he problem was not merely the very real one of the inadequate resources of the Chinese economy as a whole. In large measure the financial straits in which the Peking government found itself were due to ... [inability to] command such financial capacity as there was in its empire'. ${ }^{39}$ Part of the explanation for this inability lay in a characteristic which the Chinese state shared with other agrarian states: lower and middle level officials were recruited from the landed gentry, paid insufficient salaries, and allowed to engage in a certain amount of 'normal' corruption, withholding revenues collected as taxes from higher authorities. ${ }^{40}$ Yet, if the Manchu Dynasty had encoun-

37 Chorley, op. cit., pp. 138-9.

38 Ibid., p. 141.

39 Albert Feuerwerker, China's Early Industrialization (New York: Atheneum, 1970; originally published in 1958), p. 41.

40 Chung-li Chang, The Chinese Gentry (Seattle: University of Washington Press, 1955); Ping-ti Ho, The Ladder of Success in Imperial China (New York: Columbia University Press, 1962); and Franz Michael, 'State and Society in Nineteenth Century China', World Politics 7 (April, 1955): 419-33. 
tered the forces of modernization at the height of its powers (say in the early eighteenth century) rather than during its declining phase, it might have controlled or been able to mobilize sufficient resources to finance modern industries and equip a centrally controlled modern army. In that case, officials would never have been allowed to serve in their home provinces, and thus local and regional groups of gentry would have lacked institutional support for concerted opposition against central initiatives. But, as it happened, the Manchu Dynasty was forced to try to cope with wave after wave of imperialist intrusions, engineered by foreign industrial or industrializing nations anxious to tap Chinese markets and finances, immediately after a series of massive mid-nineteenth-century peasant rebellions. The Dynasty had been unable to put down the Taiping Rebellion on its own, and the task had fallen instead to local, gentry-led, selfdefense associations and to regional armies led by complexly interrelated gentry who had access to village resources and recruits. In consequence of the gentry's role in putting down rebellion, governmental powers formerly accruing to central authorities or their bureaucratic agents, including, crucially, rights to collect and allocate various taxes, devolved upon local, gentry-dominated, sub-district governing associations and upon provincial armies and officials increasingly aligned with the provincial gentry against the center. ${ }^{41}$

Unable to force resources from local and regional authorities, it was all Peking could do simply to meet foreign indebtedness, and after 1895 even that proved impossible.

Throughout the period from 1874 to 1894 , the ministry [of Revenue in Peking] was engaged in a series of largely unsuccessful efforts to raise funds in order to meet a continuing series of crises--the dispute over Ili with Russia, the Sino-French War [1885], floods and famines, the Sino-Japanese War [1895]. . . After 1895 the triple pressure of indemnity payments, servicing foreign loans, and military expenditures totally wrecked the rough balance between income and outlay which Peking had maintained [with the aid of foreign loans] until that time. 42

The Boxer Rebellion of 1900 , and subsequent foreign military intervention, only further exacerbated an already desperate situation.

Attempts by dynastic authorities to remedy matters through a series of 'reforms' implemented after 1900-abolishing the Confucian educational system and encouraging modern schools; ${ }^{43}$ organizing the so-called 'New Armies' (which actually formed around the nuclei of the old provincial armies ) $; 4^{44}$ transferring local governmental functions to provincial

41 Philip Kuhn, Rebellion and Its Enemies in Late Imperial China (Cambridge, Mass.: Harvard University Press, 1970).

42 Feuerwerker, op. cit., pp. 40-41.

43 Mary C. Wright, ed., China in Revolution: The First Phase, 1900-1913 (New Haven: Yale University Press, 1968), pp. 24-26.

44 Yoshiro Hatano, 'The New Armies', pp. 365-82 in Wright, ed., op. cit.; and John Gittings, 'The Chinese Army', pp. 187-224 in Jack Gray, ed., Modern China's Search for a Political Form (London: Oxford University Press, 1969). 
bureaus; ${ }^{45}$ and creating a series of local and provincial gentry-dominated representative assemblies ${ }^{46}$-only exacerbated the sorry situation, right up to the 1911 breaking point. 'Reform destroyed the reforming government'. ${ }^{47}$ With each reform, dynastic elites thought to create powers to counterbalance entrenched obstructive forces, but new officials and functions were repeatedly absorbed into pre-existing local and (especially) regional cliques of gentry. ${ }^{48}$ The last series of reforms, those that created representative assemblies, ironically provided cliques of gentry with legitimate representative organs from which to launch the liberal, decentralizing 'Constitutionalist movement' against the Manchus.

What ultimately precipitated the 'revolution of 1911 ' was a final attempt at reform by the central government, one that directly threatened the financial interests of the gentry power groups for the purpose of strengthening central government finances and control over national economic development:

The specific incident that precipitated the Revolution of 1911 was the central government's decision to buy up a [railroad] line in Szechwan in which the local gentry had invested heavily... . The Szechwan uprising, led by the moderate constitutionalists of the Railway Protection League, sparked widespread disturbances that often had no connection with the railway issue. . . .49

Conspiratorial groups affiliated with Sun Yat Sen's T'eng Meng Hui, and mainly composed of Western-educated students and middle-rank New Army officers, joined the fray to produce a series of military uprisings. Finally,

... the lead in declaring the independence of one province after another was taken by two principal elements: the military governors who commanded the New Army forces and the gentry-official-merchant leaders of the provincial assemblies. These elements had more power and were more conservative than the youthful revolutionarists of the T'eng Meng Hui. 50

The Chinese 'Revolution of 1911 ' irremediably destroyed the integument of civilian elite ties-traditionally maintained by the operation of Confucian educational institutions and the central bureaucracy's policies for recruiting and deploying educated officials so as to strengthen "cosmopolitan' orientations at the expense of local loyalties-which had until that time provided at least the semblance of unified governance for China. 'Warlord' rivalries ensued as gentry interests attached themselves to regional military machines, and this condition of intra-elite disunity and

45 John Fincher, 'Political Provincialism and the National Revolution', in Wright, ed., op. cit., p. 202.

${ }^{46}$ Fincher, op. cit; ; and P'eng-yuan Chang, 'The Constitutionalists', in Wright, ed., op. cit.

47 Wright, ed., op. cit., p. 50.

48 Fincher, op. cit.

49 Wright, ed., loc. cit.

50 John King Fairbank, The United States and China (Third Edition) (Cambridge, Mass.: Harvard University Press, 1971), p. 132. 
rivalry (only imperfectly and temporarily overcome by Chiang KaiShek's regime between 1927 and 1937) $)^{51}$ condemned China to incessant turmoils and provided openings (as well as cause) for lower-class, especially peasant, rebellions and for Communist attempts to organize and channel popular unrest.

\section{PEASA N T INSURRECTIONS}

If administrative and military breakdown in a modernizing agrarian bureaucracy were to inaugurate social revolutionary transformations, rather than merely an interregnum of intra-elite squabbling, then widespread popular revolts had to coincide with and take advantage of the hiatus of governmental supervision and sanctions. Urban insurrections provided indispensable support during revolutionary interregnums to radical political elites vying against other elites for state power: witness the Parisian sans culottes' support for the Jacobins; ${ }^{52}$ the Chinese workers' support for the Communists (between 1920 and 1927);53 and the Russian industrial workers' support for the Bolsheviks. But fundamentally more important in determining final outcomes were the peasant insurrections which in France, Russia and China constituted irreversible attacks on the powers and privileges of the traditional landed upper classes.

Agrarian bureaucracy has been the only historical variety of complex society with differentiated, centralized government that has, in certain instances, incubated a lower-class stratum that was simultaneously strategic in the society's economy and polity (as surplus producer, payer of rents and taxes, and as provider of corvée and military manpower), and yet organizationally autonomous enough to allow the 'will' and 'tactical space' for collective insurrection against basic structural arrangements.

How have certain agrarian bureaucracies exemplified such special propensity to peasant rebellion? As Eric Wolf has pointed out, 'ultimately, the decisive factor in making a peasant rebellion possible lies in the relation of the peasantry to the field of power which surrounds it. A rebellion cannot start from a situation of complete impotence. . . .54 If they are to act upon, rather than silently suffer, their omnipresent grievances, peasants must have 'internal leverage' or 'tactical mobility'. They have this to varying degrees according to their position in the total agrarian social structure. Institutional patterns which relate peasants to

51 Martin C. Wilbur, 'Military Separatism and the Process of Reunification Under the Nationalist Regime, 1922-1937, pp. 203-63 in Ping-ti Ho and Tang Tsou, eds., China in Crisis, Volume I, Book I (Chicago: University of Chicago Press, 1968).

52 Albert Soboul, The Sans Culottes (New York: Anchor Books, 1972; originally published in French in 1968); and George Rude, The Crowd in the French Revolution (London: Oxford University Press, 1959).

53 Jean Chesneaux, The Chinese Labor Movement, 1919-1927 (Stanford: Stanford University Press, 1968).

54 Eric R. Wolf, Peasant Wars of the Twentieth Century (New York: Harper and Row, 1969), p. 290. 
landlords and peasants to each other seem to be the co-determinants of degrees of peasant 'tactical mobility'. Sheer amounts of property held by peasants gain significance only within institutional contexts. If peasants are to be capable of self-initiated rebellion against landlords and state officials, they must have (a) some institutionally based collective solidarity, and (b) autonomy from direct, day-to-day supervision and control by landlords in their work and leisure activities. Agricultural regimes featuring large estates worked by serfs or laborers tend to be inimical to peasant rebellion - witness the East Elbian Junker regime ${ }^{55}$ - but the reason is not that serfs and landless laborers are economically poor, rather that they are subject to close and constant supervision and discipline by landlords or their agents. If large-estate agriculture is lacking, an agrarian bureaucracy may still be relatively immune to widespread peasant rebellion if landlords control sanctioning machineries, ${ }^{56}$ such as militias and poor relief agencies, at local levels. On the other hand, landlords as a class, and the 'system' as whole, will be relatively vulnerable to peasant rebellion if: (a) sanctioning machineries are centralized; (b) agricultural work and peasant social life are controlled by peasant families and communities themselves. These conditions prevailed in France and Russia and meant that, with the incapacitation of central administrative and military bureaucracies, these societies became susceptible to the spread and intensification of peasant revolts which in more normal circumstances could have been contained and repressed.

It is worth emphasizing that peasant actions in revolutions are not intrinsically different from peasant actions in 'mere' rebellions or riots. When peasants 'rose' during historical social revolutionary crises, they did so in highly traditional rebellious patterns: bread riots, 'defense' of communal lands or customary rights, riots against 'hoarding' merchants or landlords, 'social banditry'. Peasants initially drew upon traditional cultural themes to justify rebellion. Far from becoming revolutionaries through adoption of a radical vision of a desired new society, 'revolutionary' peasants have typically been 'backward-looking' rebels incorporated by circumstances beyond their control into political processes occurring independently of them, at the societal 'center'. ${ }^{57}$

55 In 1848 the East Elbian region of 'Germany' escaped general peasant insurrection, and the Prussian armies that crushed the German Revolutions of 1848 were recruited from the East Elbian estates, officers and rank-and-file alike. See: Theodore Hamerow, Restoration, Revolution, Recreation (Princeton, N.J.: Princeton University Press, 1958); and Hajo Holborn, A History of Modern Germany, 16481840 (New York: Alfred A. Knopf, 1963).

56 'Sanctioning machineries' are organizations which control forceful or remunerative sanctions. 'Social control' also involves normative pressures, but to be truly binding, especially in hierarchical situations, these must typically be 'backed up' by application or credible threat of application of force or manipulation of needed remuneration.

${ }^{57}$ See Wolf, op. cit., 'Conclusion'; and Moore, op. cit., Chap. 9 and 'Epilogue'. 
In the highly abnormal circumstances of social revolution, administrative breakdown, political rebellions of marginal elites, and peasant insurrections interacted to produce transformations that none alone could have occasioned or accomplished. Because peasants could rebel on their own in France and Russia, they did not have to be directly mobilized by urban radicals. In China, such mobilization was ultimately necessary, but it was for the most part a military mobilization which conformed with important modifications to an age-old pattern of elite/peasant coordination of effort to accomplish 'dynastic replacement'. As we shall see, China is the exception that proves the rule about peasant insurrectionary autonomy and social revolution.

At the end of the Old Regime, 'France was unique in Europe in that seigneurial privilege co-existed with a free peasantry owning a good deal of land ${ }^{58}$ and largely controlling the process of agrarian production. Averaging across regions, peasants owned about one-third of the land, ${ }^{59}$ subject to tithes, taxes, and seigneurial dues, and peasants probably cultivated most of the remainder as renters or sharecroppers (métayers), for large landowners rarely directly exploited their own holdings. ${ }^{60}$ The development of regional and national markets for grain and other agricultural products, a process directly and indirectly encouraged by government activities, ${ }^{61}$ spurred class differentiation within the ranks of the peasantry and fueled intra-village tensions. Laboureurs (rich peasants) with sufficient land and equipment could profit from rising prices for grain and land, but swelling masses of smallholders with insufficient land to support families were hard-pressed by rising rents and by bread prices that outstripped wage rates for agricultural or industrial labor. ${ }^{62}$ Nevertheless, virtually all peasants shared resentment of taxes, tithes, and seigneurial dues, and community institutions reinforced propensities and capacities to act together against common enemies.

58 Norman Hampson, A Social History of the French Revolution (Toronto: University of Toronto Press, 1963), p. 23.

59 Ernest Labrousse, 'The Evolution of Peasant Society in France from the Eighteenth Century to the Present', pp. 43-64 in E. M. Acomb and M. L. Brown, Jr., eds., French Society and Culture Since the Old Regime (New York: Holt, Reinhart and Winston, 1966); Georges Lefebvre, 'Repartition de la Propriété et de l'Exploitation Foncières à la Fin de l'Ancien Régime', pp. 279-306 in Georges Lefebvre, Etudes sur la Revolution Française (Paris: Presses Universitaires de France, 1963); Albert Soboul, La France à la Veille de la Revolution: Aspects Economiques et Sociaux (Paris: Centre de Documentation Universitaire, La Sorbonne, 1960), Chap. 6; and Hampson, op. cit., p. 23.

60 Alun Davies, 'The Origins of the French Peasant Revolution of 1789', History 49(165) (February, 1964), 25; and Henri Sée, Economic and Social Conditions in France During the Eighteenth Century (New York: F. S. Crofts, 1931), pp. 3-4.

61 Louise Tilly, 'The Food Riot as a Form of Political Conflict in France', The Journal of Interdisciplinary History 11(1) (Summer, 1971): 23-57.

62 Davies, op. cit.; Georges Lefebvre, The French Revolution, Volume I (New York: Columbia University Press, 1962), pp. 47-49; and Albert Soboul, 'Classes and Class Struggles During the French Revolution', Science and Society 17(5) (Summer, 1953), 243-4. 
One important effect of the traditional agricultural system was to foster a strong community-feeling in the village. The management of the open fields required uniformity of cultivation and the commons were administered by the village as a whole $\ldots$ and the allocation of taxes was a matter of common concern. The village shared rights which it might have to defend in the courts. . . In a system both traditional and partly communal there was little scope for individualism, and peasants, while recognizing the private ownership of land, were inclined to regard the harvest as the property of the community. 63

Big landlords in France exercised few local governing functions. Parish priests and rich peasants might exercise preponderant influence in village assemblies and on the local governing councils established in 1787, but in general peasant communities looked after their own affairs. ${ }^{64}$ Seigneurs or their agents still exercised prerogatives of 'feudal' justice on their estates, but military forces to back up judicial decisions, and, in general, to enforce order were controlled by the Intendants, administrative agents of the central government. ${ }^{85}$

Peasant participation in the Revolutionary drama began in the spring of 1789 with bread riots, a long-established form of popular response to conditions of grain scarcity and high bread prices. ${ }^{66}$ The winter of 1788 had been unusually severe, and an industrial depression had been underway since $1786 .{ }^{67}$ 'Irrespective of political events, there would have been widespread rioting and disorder in France during the summer of $1789^{\prime} .{ }^{68}$ But then, '. . . under the impact of economic crisis and political events, the peasant movement developed from early protests against prices, through attacks on enclosure, gaming [sic] rights, and royal forests, to a frontal assault on the feudal land system itself' ${ }^{69}$

Not that Third Estate spokesmen deliberately sought to stir up or mobilize the peasantry: leaders of the Third Estate were as anxious to protect property as were nobles; indeed many owned or administered seigneurial rights. ${ }^{70}$ Rather, the political events leading up to the calling and convening of the Estates General, and then to the fall of the Bastille and the assertion of national sovereignty by the Assembly, accelerated and focused the peasant rebellion in indirect ways. The convening of the Estates General, involving as it did the process of drawing up the cahiers, encouraged all Frenchmen to ruminate upon their social and political

${ }^{63}$ Hampson, op. cit., p. 24; also see Albert Soboul, 'The French Rural Community in the Eighteenth and Nineteenth Centuries', Past and Present, Number 10 (November, 1956), 78-95.

64 Soboul, 'French Rural Community ... ,' 80-81.

65 J. S. Bromley, 'The Decline of Absolute Monarchy', in J. M. Wallace-Hadrill and J. McManners, eds., France: Government and Society (London: Methuen, 1957).

${ }^{68}$ Tilly, op. cit.

${ }^{67}$ Lefebvre, op. cit., Chap. 8.

68 Hampson, op. cit., p. 69.

69 George Rudé, The Crowd in History (New York: Wiley, 1964), p. 103.

70 Alfred Cobban, The Social Interpretation... , Chap. 5. 
grievances and raised widespread hopes that they would be acted upon. The spread of anti-aristocratic rhetoric by Third Estate spokesmen encouraged peasants to symbolize their own difficulties in terms of an 'aristocratic plot'. ${ }^{71}$ And, finally, divisions within the elite, pitting Crown and central administration against the privileged, and the Third against the Second Estate, served to disorganize the army. ${ }^{72}$ At first, officers were reluctant to repress popular demonstrations; later lines of command were entirely muddled, as rank-and-file soldiers became politicized, and as the 'municipal revolution' caused intendants to abandon their posts and national guards to claim sole jurisdiction in matters of maintaining popular order. 'Within the space of a few weeks the royal government lost control over the provinces, for in matters of importance the towns henceforth took their orders only from the Assembly'. ${ }^{73}$ The Assembly, in turn, could not encourage systematic repression of peasant revolts by the urban national guards without playing into the hands of the Crown and the conservative nobles and hence jeopardizing all that had been gained in July, $1789 .{ }^{74}$ Thus, the peasantry, during the spring and summer of 1789 (and, in fact, thereafter for several years) was left largely free to push rebellion in rural areas beyond the largely ritualized form of the bread riot and was encouraged by what it perceived of urban upheavals to focus its attack upon one of its traditional enemies in particular: the seigneur.

The real enemy of the majority of the peasants was the large landowner, noble, bourgeois or laboureur (yeoman farmer), whose acquisitiveness was threatening them with expropriation. But the main landowner in the village was often the seigneur, who was also responsible for the . . . burden of seigneurial dues. It was not difficult to lay most economic grievances at the seigneur's door. Royal taxation woud have been lighter if the nobility had paid its full share. . . The tithe, in very many cases, went not to the local curé, but to maintain the aristocratic abbot of an almost empty monastery in luxury at Versailles, while the impoverished contributors had to make supplementary grants to maintain the village church. The countryman thus found himself locked in a circle of frustration of which privilege seemed to hold the key to every door. Consequently, the village was able, for a time, to submerge its internal divisions in a common assault on the privileges of the nobility. ... [T] The insurgent peasants made not for their seigneur's valuables but for their feudal title-deeds. 75

The 'choice' of enemy was encouraged by the fact that urban forces had also singled him out, but mainly it was inherent in the agragrian structure of the Old Regime. That structure '. . . tended to maintain the cohesion of the rural community in opposition to the landed nobility'76

71 Lefebvre, loc. cit.

72 Chorley, op. cit., Chap. 8.

73 Hampson, op. cit., p. 78.

74 Lefebvre, op. cit., p. 129.

75 Hampson, op. cit., p. 27.

76 Soboul, 'French Rural Community . . , p. 85. 
yet rendered the landed noble (and other owners of seigneurial rights) dependent upon sanctioning machineries controlled from the center. When those machineries ceased to function effectively, the fate of seigneurial property was sealed.

Historians agree that the Russian Emancipation of the serfs in 1861, intended by the Czar as a measure to stabilize the agrarian situation, actually enhanced the rebellious potential of the ex-serfs. Heavy redemption payments and inadequate land allotments fuelled peasant discontent. More important, legal reinforcement of the obshchina's (peasant commune's) authority over families and individuals fettered ever-increasing numbers of peasants to the inadequate lands, reinforced collective solidarity, retarded the internal class differentiation of the peasantry, and left communes largely free to run their own affairs subject only to the collective fulfillment of financial obligations to the state. ${ }^{77}$ Estate owners were deprived of most direct authority over peasant communities. ${ }^{78}$

Not surprisingly, given this agrarian situation, widespread peasant rebellions erupted in Russia in 1905, when the Czarist regime simultaneously confronted defeat abroad and an anti-autocratic movement of the middle classes, the liberal gentry, and the working classes at home. 'Economic hardship created a need for change; peasant tradition, as well as revolutionary propaganda, suggested the remedy [i.e., attacks on landlords and land seizures]; official preoccupation and indecisiveness invited the storm; and soon the greatest disturbance since the days of Pugachev was under way'. ${ }^{79}$

In the wake of the unsuccessful Revolution of 1905, the Czarist regime abandoned its policy of shoring up the peasant commune. It undertook the break-up of repartitional lands into private holdings and implemented measures to facilitate land sales by poorer peasants and purchases by richer ones. ${ }^{80}$ Between 1905 and 1917, these measures, in tandem with general economic developments, did something to alleviate agrarian stagnation, promote permanent rural migration to urban industrial areas, and increase class differentiation and individualism in the countryside. ${ }^{81}$ However, by 1917 , little enough had been accomplishedonly one-tenth of all peasant families had been resettled on individual

77 Terence Emmons, 'The Peasant and the Emancipation', and Francis M. Watters, 'The Peasant and the Village Commune', both in Wayne S. Vucinich, ed., The Peasant in Nineteenth-Century Russia (Stanford: Stanford University Press, 1968); and Robinson, op. cit.

78 Jerome Blum, Lord and Peasant in Russia (Princeton, N.J.: Princeton University Press, 1961), pp. 598-9; and Robinson, op. cit., pp. 78-79.

79 Robinson, op. cit., p. 155.

80 lbid., pp. 188-207.

81 Gerschenkron, op. cit., pp. 42-72. 
holdings ${ }^{82}$ - that peasant communities engaged in solidary actions against both landlords and any rich peasant 'separators' who did not join their struggle.

'Any shrewd observer of Russian conditions who weighed the lessons of the agrarian disorders of 1905 could have foreseen that a breakdown of central power and authority was almost certain to bring an even greater upheaval in its train' ${ }^{83}$ And, indeed, between the spring and the autumn of 1917 , 'side by side with the mutiny of the Russian army marched a second great social revolutionary movement: the seizure of the landed estates by the peasantry'. ${ }^{84}$

The peasant movement of 1917 was primarily a drive of the peasantry against the pomyeschik class. Among the cases of agrarian disturbance, violent and peaceful, 4,954, overwhelming the largest number, were directed against landlords, as against 324 against the more well-to-do peasants, 235 against the Government and 211 against the clergy. 85

The broad general result of the wholesale peasant land seizure of 1917 was a sweeping levelling in Russian agriculture. The big latifundia, even the small estate, ceased to exist. On the other hand landless or nearly landless peasants obtained larger allotments. ${ }^{86}$

For the peasants simply applied traditional communal repartitional procedures to lands seized from the landlords. Their revolt, together with the Bolsheviks' victory, '.. sealed forever the doom of the old landed aristocracy'. ${ }^{87}$

The Chinese case presents decisive contrasts with France and Russia but nevertheless confirms our general insight about the importance of structurally conditioned 'tactical space' for peasant insurrection as a crucial factor in the translation of administrative/military breakdown into social revolution.

Except in infertile and marginal highland areas, Chinese peasants, though mostly family smallholders or tenants, ${ }^{88}$ did not live in their own village communities clearly apart from landlords.

The Chinese peasant ... was a member of two communities: his village and the marketing system to which his village belonged ['typically including fifteen to twentyfive villages ... d dependent on one of 45,000 market towns]. An important feature of the larger marketing community was its elaborate system of stratification. . . . Those who provided de facto leadership within the marketing community qua political system and those who gave it collective representation at its interface with

82 Robinson, op. cit., pp. 225-6.

83 Chamberlin, op. cit., p. 257.

84 Ibid., p. 242.

85 Ibid., p. 252.

86 Ibid., p. 256.

87 Ibid., p. 256.

88 R. H. Tawney, Land and Labour in China (Boston: Beacon Press, 1966; originally published in 1932), Chap. 2. 
larger polities were gentrymen-landed, leisured, and literate. . . . It was artisans, merchants, and other full-time economic specialists, not peasants, who sustained the heartbeat of periodic marketing that kept the community alive. It was priests backed by gentry temple managers ... who gave religious meaning to peasants' local world. 89

Voluntary associations, and clans where they flourished, were likewise contained within marketing communities, headed and economically sustained by gentry. Thus kinship, associational and clientage ties cut across class distinctions between peasants and landlords in traditional China. Gentry controlled at local levels a variety of sanctioning machineries, including militias and other organizations which functioned de facto as channels of poor relief. ${ }^{90}$

Not surprisingly, therefore, settled Chinese peasant agriculturalists did not initiate class-based revolts against landlords, either in pre-modern or in revolutionary (1911-49) times. Instead, peasant rebellion manifested itself in the form of accelerating rural violence and social banditry, spreading outward from the mountainous 'border areas' at the edges of the empire or at the intersections of provincial boundaries. Social banditry invariably blossomed during periods of central administrative weakness or collapse and economic deflation and catastrophe. Precisely because normal traditional Chinese agrarian-class relations were significantly commercialized, local prosperity depended upon overall administrative stability, and peasants were not cushioned against economic dislocations by kin or village communal ties. During periods of dynastic decline, local (marketing) communities 'closed in' upon themselves normatively, economically, and coercively, ${ }^{91}$ and poorer peasants, especially in communities without well-to-do local landed elites, lost property and livelihood, and were forced to migrate. Such impoverished migrants often congregated as bandits or smugglers operating out of 'border area' bases and raiding settled communities. Ultimately they might provide (individual or group) recruits for rebel armies led by marginal elites vying for imperial power. ${ }^{92}$

The nineteenth and the first half of the twentieth centuries constituted a period of dynastic decline and interregnum in China, complicated in quite novel ways by Western and Japanese economic and military intrusions. Peasant impoverishment, local community closure, spreading social banditry and military conflicts among local militias, bandit groups,

89 G. William Skinner, 'Chinese Peasants and the Closed Community: An Open and Shut Case', Comparative Studies in Society and History 13(3) (July, 1971), pp. 272-3.

90 Kuhn, op. cit., passim.

91 Skinner, op. cit., $278 \mathrm{ff}$.

02 See: Skinner, op. cit., Kuhn, op. cit.; and George E. Taylor, 'The Taiping Rebellion: Its Economic Background and Social Theory', Chinese Social and Political Science Review 16 (1933): 545-614. 
and warlord and/or 'ideological' armies, characterized the entire time span, and peaked during the mid-nineteenth and mid-twentieth centuries.

The Communist movement originated as a political tendency among a tiny fraction of China's nationalist and pro-modern intellectual stratum and created its first mass base among Chinese industrial workers concentrated in the treaty ports and to a lesser degree among students and southeast Chinese peasants. But after 1927, the Chinese Communists were forced out of China's cities and wealthier agrarian regions by Kuomintang military and police repression. Would-be imitators of the Bolsheviks were thus forced to come to terms with the Chinese agrarian situation. This they did initially (between 1927 and 1942) by recapitulating the experiences and tactics of traditional rebel elite contenders for imperial power in China. Scattered, disorganized and disoriented Communist leaders, along with military units (which had split off from KMT or warlord armies) of varying degrees of loyalty, retreated to mountainous border areas, there often to ally with already existing bandit groups. ${ }^{93}$ Gradually the fruits of raiding expeditions, plus the division and weakness of opposing armies, allowed the 'Communist' base areas to expand into administrative regions.

Only after a secure and stable administrative region had finally been established in Northwest China (after 1937) could the Communists finally turn to the intra-market-area and intra-village political organizing that ultimately bypassed and then eliminated the gentry, and so made their drive for power unique in China's history. Before roughly 1940, ideological appeals, whether 'Communist' or 'Nationalist' played little role in mediating Communist elites' relations to peasants, and spontaneous class struggle, fuelled from below, played virtually no role in achieving whatever (minimal) changes in agrarian class relations were accomplished in Communist base areas. ${ }^{94}$ To be sure, ideology was important in integrating the Party, an elite organization, and in mediating its relationship with the Red Army. But until Party and Army established relatively secure and stable military and administrative control over a region, Communist cadres were not in a position to penetrate local communities in order to provide organization, leadership, and encouragement for peasants themselves to expropriate land. This finally occurred in

93 See: Mark Selden, The Yenan Way in Revolutionary China (Cambridge, Mass.: Harvard University Press, 1971), Chaps. 1-2; Dick Wilson, The Long March 1935 (New York: Avon Books, 1971); and Agnes Smedly, The Great Road: The Life and Times of Chu Teh (New York: Monthly Review Press, 1956).

${ }^{94}$ Selden, op. cit.; Franz Schurmann, Ideology and Organization in Communist China (second edition) (Berkeley and Los Angeles: University of California Press, 1968), pp. 412-37; Ilpyong J. Kim, 'Mass Mobilization Policies and Techniques Developed in the Period of the Chinese Soviet Republic', pp. 78-98 in A. Doak Barnett, ed., Chinese Communist Politics in Action (Seattle: University of Washington Press, 1969). 
even given administrative/military collapse. In pre-modern times, France, North China in the $1940 \mathrm{~s}^{95}$ Once provided with military and organizational protection from landlord sanctions and influence, peasants often reacted against landlords with a fury that exceeded even what Party policy desired. Perhaps Communist ideological appeals were partially responsible for peasant insurrection. More likely, even at this stage, the Communist organizations' important input to local situations was not a sense of grievances, or their ideological articulation, but rather simply protection from traditional social controls: William Hinton's classic Fanshen: A Documentary of Revolution in a Chinese Village vividly supports such an interpretation..$^{96}$

Even to gain the military strength they needed to defeat the Kuomintang, the Chinese Communists had to shove aside-or encourage and allow peasants to shove aside-the traditional landed upper class and establish a more direct link to the Chinese peasantry than had ever before been established between an extra-local Chinese rebel movement and local communities. ${ }^{97}$ The Chinese Communists also established more direct links to peasants than did radical elites in Russia or France. The Chinese Revolution, at least in its closing stages, thus has more of the aspect of an elite/mass movement than the other great historical social revolutions. Yet the reasons for this peasant mass-mobilizing aspect have little to do with revolutionary ideology (except in retrospect) and everything to do with the 'peculiarities' (from a European perspective) of the Chinese agrarian social structure. That structure did not afford settled Chinese peasants institütional autonomy and solidarity against landlords, yet it did, in periods of political-economic crisis, generate marginal poorpeasant outcasts whose activities exacerbated the crises and whose existence provided potential bases of support for oppositional elite-led rebellions or, in the twentieth-century world context, a revolutionary movement. Thus Chinese Communist activities after 1927 and ultimate triumph in 1949 depended directly upon both the insurrectionary potentials and the blocks to peasant insurrection built into the traditional Chinese social structure.

\section{RADICAL POLITICAL MOVEMENTS AND CE NTRA LIZING OUTCOMES}

Although peasant insurrections played a decisive role in each of the great historical social revolutions, nevertheless an exclusive focus on peasants -or on the peasant situation in agrarian bureaucracies-cannot provide a complete explanation for the occurrence of social revolutions,

05 Selden, op. cit.; and Schurmann, op. cit.

96 William Hinton, Fanshen: A Documentary of Revolution in a Chinese Village (New York: Vintage Books, 1968; first published in 1966).

97 Schurmann, op. cit., pp. 425-31. 
Russia and China were recurrently rocked by massive peasant rebellions, ${ }^{98}$ yet peasant uprisings did not fuel structural transformations until the late eighteenth century and after. Obviously agrarian bureaucracies were exposed to additional and unique strains and possibilities once English and then European commercialization-industrialization became a factor in world history and development. The stage was set for the entry of marginal elites animated by radical nationalist goals.

Who were these marginal elites? What sectors of society provided the social bases for nationalist radicalisms? Not the bourgeoisie proper: merchants, financiers and industrialists. These groups have had surprisingly little direct effect upon the politics of modernization in any developing nation, from England to the countries of the Third World today. Instead, their activities, commerce and manufacturing, have created and continuously transformed, indeed revolutionized, the national and international contexts within which bureaucrats, professionals, politicians, landlords, peasants, and proletarians have engaged in the decisive political struggles. To be sure, in certain times and places, the 'bourgeois' commercial or industrial context has been pervasive enough virtually to determine political outcomes, even without the overt political participation of bourgeois actors. But such was not the case in the earlier modernizing agrarian bureaucracies, including France, Russia and China.

Instead, nationalist radicals tended to 'precipitate out' of the ranks of those who possessed specialized skills and were oriented to state activities or employments, but either lacked traditionally prestigious attributes such as nobility, landed wealth, or general humanist education, or else found themselves in situations where such attributes were no longer personally or nationally functional. Their situations in political and social life were such as to make them, especially in times of political crises, willing to call for such radical reforms as equalization of mobility opportunities, political democracy, and (anyway, before the revolution) extension of civil liberties. Yet the primary orientation of these marginal elites was toward a broad goal that they shared with all those, including traditionally prestigious bureaucrats, whose careers, livelihoods, and identities were intertwined with state activities: the goal of extension and rationalization of state powers in the name of national welfare and prestige.

In Bourbon France, radicals (of whom the Jacobins were the most extreme) came primarily from the ranks of non-noble, non-wealthy lawyers, professionals, or state functionaries, and disproportionately from the provinces.

98 See, for example, Roland Mousnier, Peasant Uprisings in the Seventeenth Century: France, Russia and China (New York: Harper and Row, 1972; originally published in French, 1967). 
The royal bureaucracy, with its host of minor juridico-administrative officers, the professional civil servants of the great ministeries, the crowds of lawyers, the doctors, surgeons, chemists, engineers, lower army officers . . . all of these formed a social nexus which provided the men who did most of the work of government as well as of the professions, but who were kept out of the higher offices by lack of noblesse or of sufficient wealth to purchase it, and humiliated socially by the thought that they belonged to a lower caste. 99

In the market towns and small administrative centers a new class of bourgeois (that is, non-noble) lawyers had grown up to defend the interests of the provincial members of the monarchial society. It was they who seem to have suffered most, or at least most consciously, from the delaying and obfuscating tactics of the aristocratic courts and therefore best understood the pall that privilege cast over all administrative efforts at reform. Through the famous corresponding societies, these provincial critics exchanged ideas and laid the intellectual foundation for much that happened in 1789 and after.100

In Russia, by 1917, the revolutionary sects, such as the Bolsheviks and the Left Social Revolutionaries, constituted the surviving politically organized representatives of what had earlier been an outlook much more widespread among university-educated Russians: extreme alienation, disgust at Russia's backwardness, preoccupation with public events and yet refusal to become involved in the round of civil life. ${ }^{101}$ As Russia underwent rapid industrialization after 1890, opportunities for university education were extended beyond the nobility-a circumstance which helped to ensure that universities would be hotbeds of political radicalism-yet, before long, opportunities for professional and other highly skilled employments also expanded. Especially in the wake of the abortive 1905 Revolution, Russia's university-educated moved toward professional employments and liberal politics. ${ }^{102}$ Yet when events overtook Russia in 1917, organized radical leadership was still to be found among the alienated intelligentsia.

In China, as in Russia, radical nationalist modernizers came from the early student generations of university-educated Chinese. ${ }^{103}$ Especially

99 Cobban, $A$ History . . , p. 134. See also: Hampson, $A$ Social History . . , p. 60; and Georges Lefebvre, The French Revolution, Volume I (New York: Columbia University Press, 1962), p. 45.

100 Fox, op. cit., pp. 89-90.

101 George Fischer, 'The Intelligentsia and Russia', pp. 253-73 in Black, ed., op. cit.

102 George Fischer, 'The Russian Intelligentsia and Liberalism', pp. 317-36 in Hugh McLean, Martin Malia and George Fischer, eds., Russian Thought and Politics-Harvard Slavic Studies, Volume IV (Cambridge, Mass.: Harvard University Press, 1957); and Donald W. Treadgold, 'Russian Radical Thought, 1894-1917', pp. 69-86 in Stavrou, ed., op. cit.

103 John Israel, 'Reflections on the Modern Chinese Student Movement', Daedalus (Winter, 1968) : 229-53; and Robert C. North and Ithiel de Sola Pool, 'Kuomintang and Chinese Communist Elites', pp. 319-455 in Harold D. Lasswell and Daniel Lerner, eds., World Revolutionary Elites (Cambridge, Mass.: The M.I.T. Press, 1966). 
at first, most were the children of traditionally wealthy and prestigious families, but urban and 'rich peasant' backgrounds, respectively, came to be overrepresented in the (pre-1927) Kuomintang and the Communist elites. ${ }^{104}$ With the abolition of the Confucian educational system in 1904, and the collapse of the imperial government in 1911, even traditionally prestigious attributes and connections lost their meaning and usefulness. At the same time, neither warlord regimes, nor the Nationalist government after 1927 offered much scope for modern skills or credentials; advancement in these regimes went only to those with independent wealth or personal ties to military commanders. Gradually, the bulk of China's modern-educated, and especially the young, came to support the Communist movement, some through active commitment in Yenan, others through passive political support in the cities. ${ }^{105}$

Two considerations help to account for the fact that radical leadership in social revolutions came specifically from the ranks of skilled and/or university-educated marginal elites oriented to state employments and activities. First, agrarian bureaucracies are 'statist' societies. Even before the era of modernization official employments in these societies constituted both an important route for social mobility and a means for validating traditional status and supplementing landed fortunes. Second, with the advent of economic modernization in the world, state activities acquired greater-than-ever objective import in the agrarian bureaucratic societies which were forced to adapt to modernization abroad. For the concrete effects of modernization abroad first impinged upon the state's sphere, in the form of sharply and suddenly stepped up military competition or threats from more developed nations abroad. And the cultural effects of modernization abroad first impinged upon the relatively highly educated in agrarian bureaucracies, that is upon those who were mostly either employed by the state or else connected or oriented to its activities. (This is obvious for Russia and China. Consider as well the fascination of educated French officials and laymen during the eighteenth century with British economic and political models and ideas. ${ }^{106}$ Understandably, as agrarian bureaucracies confronted modernization abroad, the state was viewed by virtually everyone, from conservative reformers to radicals and revolutionaries, as the likely tool for implementation of reforms at home and enhancement of national standing in the international context. This was true for eighteenth-century France, as well as for pre-revolutionary Russia and China. Edward Fox has remarked on the irony of the fact that

104 North and Pool, op. cit.

105 John Israel, Student Nationalism in China: 1927-1937 (Stanford: Hoover Institute Publications, 1966).

106 See: Fox, op. cit., Chap. 4, and Behrens, op. cit. 
in the middle of what has been described as the 'democratic revolution,' an entire generation of gifted social critics and publicists should all but unanimously demand the royal imposition of their various programs of reform. In the theoretical and polemical literature of the time, the 'absolute' monarchy was criticized for its failure to exercise arbitrary power. To Frenchmen of the ancien régime, it was the monarchy that represented what was modern and progressive and political 'liberties' that appeared anachronistic. ... For virtually all the inhabitants of continental France, fiscal and judicial reforms were far more urgent issues than the development of political liberty; and the monarchy was the obvious agency for their implementation. Only the King's failure to live up to their expectations drove his subjects to intervene. 107

The earlier modernizing agrarian bureaucracies that (to varying degrees) successfully adapted to challenges from abroad did so either through revolution, or basic reforms 'from above' or social revolution 'from below'. Either traditional bureaucrats successfully promoted requisite reforms or else their attempts precipitated splits within the upper class which could, if the peasantry were structurally insurrection-prone, open the door to social revolution. In the context of administrative/military disorganization and spreading peasant rebellions, tiny, organized radical elites that never could have created revolutionary crises on their own gained their moments in history. As peasant insurrections undermined the traditional landed upper classes, and the old regime officials and structures tied to them, radical elites occupied center stage, competing among themselves to see who could seize and build upon the foundations of central state power.

'A complete revolution', writes Samuel Huntington, ' . . involves . . . the creation and institutionalization of a new political order'. ${ }^{108} \mathrm{~A}$ social revolution was consummated when one political elite succeeded in creating or capturing political organizations-a revolutionary army, or a revolutionary party controlling an army-capable of restoring minimal order and incorporating the revolutionary masses, especially the peasantry, into national life. No political elite not able or willing to accept the peasants' revolutionary economic gains could hope to emerge victorious from the intra-elite or inter-party conflicts that marked revolutionary interregnums. Elites with close social or politico-military ties to traditional forms of landed upper-class institutional power (i.e., the privileged rentier bourgeoisie of France, the Kerensky regime in Russia, the [post-1927] Kuomintang in China) invariably lost out.

The historical social revolutions did not culminate in more liberal political arrangements. At opening stages of the French, Russian (1905) and Chinese revolutions, landed upper-class/middle-strata political coalitions espoused 'parliamentary liberal' programs. ${ }^{109}$ But events pushed

107 Fox, op. cit., p. 90.

108 Huntington, op. cit., p. 266.

109 See: Hampson, A Social History . . , Chap. 2; Sidney Harcave, The Russian 
these groups and programs aside, for the organized elites who provided the ultimately successful leadership in all social revolutions ended up responding to popular turmoil-counterrevolutionary threats at home and abroad, peasant anarchist tendencies, and the international crises faced by their societies-by creating more highly centralized, bureaucratized and rationalized state institutions than those that existed prior to the revolutions. This response, moreover, was entirely in character for elites adhering to world views which gave consistent primacy to organized political action in human affairs. ${ }^{110}$

The strengthening and rationalizing of central state powers was the result of the French Revolution as surely as of the Russian and Chinese. In assessing the basic changes wrought by the French Revolution, Franklin Ford assigns greatest importance, after the elimination of the estate system, to administrative, political and military transformations. After 1789 , 'citizen' masses were incorporated into politics, at least symbolically, and via the 'levée en masse' into the national army. More important, France

came out of the revolutionary-Napoleonic crisis with its administrative organization profoundly and ... irreversibly altered. ... After 1815 , France retained a set of budgetary procedures, a network of departmental prefects, and a system of centrally appointed judges in the place of the deficit financing ex post facto, the quaint chaos of provincial powers, and the court system based on ownership of office with which the old monarchy had lived for centuries.111

Within France, Napoleon on the whole maintained the civil equality won during the Revolution, at least in the restricted sense in which birth conferred no formal privilege. Such of the legacy of the Enlightenment as related merely to national efficiency, for example internal free trade and advanced technical education, became a permanent part of French society. But much that the Enlightenment regarded as essential disappeared, notably freedom of the press and freedom from arbitrary arrest. In many respects Napoleonic France was closer than the France of Louis XV to Montesquieu's conception of despotism. ${ }^{112}$

The 'liberal' reforms which were put forward in all the historical social revolutions alike were guarantees of equal personal rights for all citizens. Alone they are not enough to warrant labelling any political regime 'liberal'.

Revolution of 1905 (London: Collier Books, 1970; first published in 1964); and P'eng-yuan Chang, 'The Constitutionalists', pp. 143-83 in Wright, ed., op. cit.

110 On the Bolsheviks, see Robert V. Daniels, 'Lenin and the Russian Revolutionary Tradition', pp. 339-54 in McLean, Malia and Fischer, eds., op. cit. Daniels argues that "the more autocratic societies like pre-revolutionary Russia . . . prompted historical theories which put a premium on individual will, power and ideas . . ', p. 352.

111 Franklin L. Ford, 'The Revolutionary-Napoleonic Era: How Much of a Watershed?'American Historical Review 69(1) (October, 1963), 22-23.

112 Norman Hampson, The Enlightenment (Baltimore: Penguin Books, 1968), p. 262. 
Thus, what changed most thoroughly in all of the historical social revolutions was the mode of societal control of the lower strata. Landed upper classes lost (at least) their special socio-political authority and their roles in controlling the peasantry (however feebly) through local and regional quasi-political institutional arrangements-the parlements and seigneurial courts in France; zemstvos and landed estates in Russia; clans, associations, sub-district, district and provincial governments in China. The peasantry and the urban lower strata were directly incorporated into now truly national polities and economies, institutionally and symbolically.

But wasn't the French Revolution a 'bourgeois' revolution, in contrast to the 'communist' Chinese and Russian Revolutions? Throughout, this essay has emphasized patterns common to all three of the great historical revolutions, thus violating much of the common wisdom about the special 'bourgeois' nature of the French Revolution. The traditional argument about the French Revolution holds that it was in some sense made by a 'strong' bourgeois economic class, and 'cleared the way' politically, judicially and socially for capitalist industrialization in France.

Proponents of the view that the French Revolution was a 'bourgeois revolution' can point to evidence which seems to support their position. The French Revolution did not result in the complete elimination of property-owning upper classes. ${ }^{113}$ Neither did political elites take direct control of the economy to spur national industrialization. Regional, estate and guild barriers to the formation of a national market were eliminated. And, in time, France did undergo capitalist industrialization.

Yet there are equally important facts which contradict the thesis of the 'bourgeois revolution'. Before the Revolution, French 'industry' was overwhelmingly small-scale and non-mechanized, ${ }^{114}$ and commercial and financial capital coexisted non-antagonistically, indeed symbiotically, with the more settled and prestigious 'proprietary' forms of wealth (land, venal office, annuities). ${ }^{115}$ During the Revolution, political leadership for the Third Estate was overwhelmingly recruited from the ranks of professionals (especially lawyers), office-holders, and intellectuals, not commercial or industrial bourgeois. The men who ruled France after the Revolution were bureaucrats, landowners, soldiers, commercial and financial capitalists, much as before. ${ }^{116}$ Economically relevant reforms enacted during the Revolution were largely the culmination of ' . . . the century old movement [started by Colbert] for the abolition of internal customs . . . [a movement] . . . led throughout, and ultimately brought

113 Hampson, A Social History ..., Chap. 10.

114 Sée, op. cit., pp. 172-3.

115 George V. Taylor, 'Noncapitalist Wealth and the Origins of the French Revolution', American Historical Review 72(2) (January, 1967): 469-96.

116 Cobban, Social Interpretation . . . , Chaps. 12 and 13. 
to success, not by the representatives of commercial and industrial interests, but by reforming officials'.117

From the point of view of what might have optimized conditions for French national industrialization, the French Revolution seems best interpreted as either overwrought or premature. A few ministerial reforms under the Old Regime might well have optimized chances for France quickly to emulate British industrial developments (especially since Old Regime officials were leaning toward a system of international free trade, as exemplified by the Commercial Treaty of 1786). Social revolution in France, as in Russia and China, strengthened national political institutions, equipped them to mobilize people and resources to meet the crises of modernization, to guarantee order at home, and to counter foreign threats. Yet in Russia and China, emerging from revolutionary crises in the twentieth century, strengthened national political institutions could be used directly to promote enterprises already implanted by foreign capital and employing models and advanced technologies from abroad. But in post-Revolutionary France, resources mobilized by strengthened national institutions were dissipated in the adventuristic Napoleonic Wars, while France lost ground against her chief economic competitor, Great Britain. The outcome could hardly have been different. A French economy consisting entirely of small-scale agricultural and (mostly non-mechanized) industrial units could hardly be directed from above (as the Jacobin interlude proved), ${ }^{118}$ especially when foreign models of large-scale industry were as yet in world history entirely lacking.

The French Revolution was remarkably similar to the Russian and the Chinese in its basic causes - failure of old regime officials to mobilize sufficient national resources to promote national economic development and/or counter military competition or threats from more developed nations abroad-and in its structural dynamics-peasants and marginal political elites against a traditional landed upper class. That outcomes differed-that in France no communist party emerged to fully displace landed wealth, collectivize agriculture, and direct industrializationis not only attributable to factors stressed by traditional theories of revolution, such as the shape of the pre-revolutionary class structure ${ }^{119}$ and the established ideological aims of avowed revolutionary elites, but also to the opportunities and requirements for state initiatives in indus-

117 Ibid., p. 70.

118 On the difficulties with attempts to impose economic controls during the Jacobin ascendance, see: Soboul, The Sans Culottes, 'Conclusion'; and Moore, op. cit., pp. 70-92.

119 Normally 'class structure' is analyzed only or mainly with reference to the mode of production of a society, but state organization and activities influence patterns of stratification as well. State influences were crucial in creating social forces that played key roles in the great historical social revolutions. 
trialization presented by the world political economy at the time each agrarian bureaucratic society was incorporated into a modernizing world and experienced social revolutionary transformation 'in response'.

Let me sum up what this essay has attempted to do. To explain the great historical social revolutions, I have, first, conceptualized a certain type of society, the agrarian bureaucracy, in which social control of the lower strata (mainly peasants) rests with institutions locally and regionally controlled by landed upper classes, together with administrative and military machineries centrally controlled; and second, I have discussed differences between agrarian bureaucracies which did and those which did not experience social revolutions in terms of (a) institutional structures which mediate landed upper-class relations to state apparatuses and peasant relations to landed upper classes and (b) types and amounts of international political and economic pressures (especially originating with more developed nations) impinging upon agrarian bureaucracies newly incorporated into the modernizing world. According to my analysis, social revolutions occurred in those modernizing agrarian bureaucracies -France, Russia and China-which both incubated peasantries structurally prone to autonomous insurrection and experienced severe administrative and military disorganization due to the direct or indirect effects of military competition or threats from more modern nations abroad.

In the process of elucidating this basic argument, I have at one point or another alluded to evidence concerning Prussia (Germany), Japan (and Turkey), and Russia in 1905. Obviously the coverage of these and other 'negative' cases has been far from complete. Yet partial explanations have been offered for the avoidance of social revolution by Prussia/Germany, Japan and Russia through 1916. Japan and Russia escaped administrative/military collapse in the face of moderate challenges from abroad because their traditional governmental elites were significantly differentiated from landed upper classes. Prussia lacked a structurally autonomous, insurrection-prone peasantry, and therefore when, in 1848, the King hesitated for a year to use his armies to repress popular disturbances, the Junker-led army, manned by peasants from the estates east of the Elbe, remained loyal and intact until it was finally used to crush the German Revolutions during 1849-50.

This comparative historical analysis has been meant to render plausible a theoretical approach to explaining revolutions which breaks with certain long-established sociological proclivities. While existing theories of revolution focus on discontent, and its articulation by oppositional programs or ideologies, as the fundamental cause of revolutions, I have emphasized mechanisms and dynamics of societal social control through political and class domination. Moreover, while other theories view the 
impact of modernization (as a cause of revolution) in terms of the effects of processes of economic development on class structures, 'system equilibrium', or societal members' levels of satisfaction, my approach focuses on the effects of modernization-viewed also as an inter-societal politicostrategic process - upon adaptive capacities of the agrarian bureaucratic states and upon the opportunities open to political elites who triumph in revolutions.

Obviously, thorough testing of these ideas will require more precise delineation of concepts and the extension of hypotheses derived from this analysis to new cases. But I have made a start. And I hope that especially those who disagree with my conclusions will themselves turn to historical evidence to argue their cases. Social science can best grow through the interplay of theory and historical investigation, and comparative historical analysis represents one indispensable tool for achieving this. 